DIGITAL COMMONS
@ UNIVERSITY OF SOUTH FLORIDA

Volume 11

Issue 1 Summer 2021

\section{ABO: Interactive Journal for Women in the Arts, 1640-1830}

\title{
Customary Law and the Revival of Natural Rights Reformism in Amelia Opie's Adeline Mowbray
}

\author{
Mark Zunac \\ University of Wisconsin-Whitewater, zunacm@uww.edu
}

Follow this and additional works at: https://digitalcommons.usf.edu/abo

Part of the Dramatic Literature, Criticism and Theory Commons, Educational Methods Commons, Feminist, Gender, and Sexuality Studies Commons, and the Literature in English, British Isles Commons

\section{Recommended Citation}

Zunac, Mark (2021) "Customary Law and the Revival of Natural Rights Reformism in Amelia Opie's Adeline Mowbray," ABO: Interactive Journal for Women in the Arts, 1640-1830: Vol.11: Iss.1, Article 4. http://doi.org/10.5038/2157-7129.11.1.1263

Available at: https://digitalcommons.usf.edu/abo/vol11/iss1/4

This Scholarship is brought to you for free and open access by Digital Commons @ University of South Florida. It has been accepted for inclusion in ABO: Interactive Journal for Women in the Arts, 1640-1830 by an authorized administrator of Digital Commons @ University of South Florida. For more information, please contact digitalcommons@usf.edu. 


\title{
Customary Law and the Revival of Natural Rights Reformism in Amelia Opie's Adeline Mowbray
}

\begin{abstract}
This essay investigates the role of natural law within the philosophical debates in 1790s Britain over the origins and applicability of citizens' rights, an issue amplified by memories of the French Revolution. It marks Amelia Opie's 1805 novel Adeline Mowbray as representative of a counterrevolutionary faction focused extensively on the rights of citizens, yet fully distinct from the theoretically grounded cosmopolitan vision of both the French Jacobins and their radical British counterparts. The novel serves as evidence that the British counterrevolution was not intrinsically opposed to reform, and that reform itself was not incompatible with moral duty and social good nor antithetical to a more nationalistic though broadly based - conception of "rights." In fact, it seems to be presented by Opie as a conscious alternative to revolutionary theories of universal right, by 1805 viewed by many as the progenitor of the political violence that had ensued following the fall of the Bastille sixteen years earlier.
\end{abstract}

\section{Keywords}

Amelia Opie, Adeline Mowbray, Natural Rights, French Revolution, British literature, counterrevolution, conservatism

\section{Creative Commons License}

(c) (1) (8)

This work is licensed under a Creative Commons Attribution-Noncommercial 4.0 License 
I do not vilify theory and speculation-no, because that would be to vilify reason itself. . . . No, whenever I speak against theory, I mean always a weak, erroneous, fallacious, unfounded, or imperfect theory; and one of the ways of discovering that it is a false theory is by comparing it with practice. Edmund Burke, Speech in Commons, 7 May 1782

Edmund Burke's affiliation with tradition has become proverbial, and his Reflections on the Revolution in France is a landmark within the history of intellectual conservatism. Yet the epigraph that opens this essay illustrates the complexity of tradition's defense, particularly when confronted with such seemingly unassailable virtues as those adumbrated by the revolutionary moment. It also anticipates the divergent responses of certain contemporary writers and thinkers who, while amenable to social reform, remained deeply skeptical of what Burke elsewhere called the "untried policy" (33) of the radical Revolution. Amelia Opie was such a figure, and her friendships with Mary Wollstonecraft and William Godwin during the 1790s have prompted much critical inquiry into her ambivalent treatment of radical ideas in her fiction. Yet, as Miriam Wallace has indicated, much of the criticism has relied on the contemporary dichotomylargely framed by the English counterrevolution-between Jacobin and antiJacobin writers. ${ }^{1}$ This has been problematic for scholars seeking to rationalize Opie's personal affiliation with two of the age's foremost radicals or reconcile it with the seemingly incongruous conservatism emanating from her work. ${ }^{2}$ Indeed, Opie resists facile classification, a task further complicated by the counterrevolution's application of the Jacobin label to even modest reform efforts. The legacy of this reductive delineation has, as Catherine Packham has argued, "prevent[ed] a fuller discussion of the historical thinking and methodologies shared by both sides in the post-Revolutionary debates" (147). As such, Opie's refuge in a seemingly conservative politics, even before her conversion to the Society of Friends in 1824, was not just defensive posturing nor, as Wallace adroitly terms it, a "repressed, palimpsestic resistance" (208). Rather, much of Opie's work suggests that the conservative, loyalist disposition need not have been opposed to a serious consideration of moral duty and social good. Such an approach is vastly different than writing conservatively as a professional expedient, a gambit that would ultimately have compromised the author's artistic autonomy and blunted her political acuity. To be sure, Opie presents a more politically palatable response to the Revolution's excesses. But this approach is not a concession intended to conceal a natural affinity for revolutionary ideals as

${ }^{1}$ See, in particular, $14-20$.

${ }^{2}$ See, for example, Wake and King. 
has often been assumed. It, instead, secures Opie's place in a novelistic tradition that marks the compatibility, rather than the tension, between conservatism and reform. ${ }^{3}$

Burke posited that the prospect of arbitrary rule by absolute democracy would prove more despotic than corrupted structures of existing government, a theme that recurs in much Romantic-era literature dealing with the establishment —or transgression - of sociocultural norms and institutions. Yet while popular sentimental novels such as Hannah Foster's The Coquette (1797) and Maria Edgeworth's Letters to Literary Ladies (1795) have evoked conflicting responses regarding the punishment of their heroines for violating social norms, the focus remains largely on the acts of transgression themselves. Thus, these texts have been read alternately as didactic and subversive, leaving readers to ponder questions about the object of condemnation. However, the heroines of these novels, particularly The Coquette, seem to mimic social stereotypes of the woman insistent on "marriage to a man with wealth and position enough to guarantee a life of idle luxury and endless socializing" (Korobkin 79). And while any critiques made by the authors of these novels might be directed at the society that produces limited options and little education for women - or at the women themselves - for heroines like The Coquette's Eliza, "rebellion is neither a political protest nor a strike for freedom as we would understand that term" (Korobkin 79). In essence, the act of social rebellion does not always constitute an overt evaluation of those systems - political, philosophical, or otherwise - that invariably influence the social order.

What will be discussed here, then, is Amelia Opie's post-revolutionary novel Adeline Mowbray (1804), which, perhaps more than any of Opie's other work, indicates that a critique and even renunciation of radical, and in this case, specifically Godwinian ideology does not preclude a desire to reform. However, whereas Wallace is concerned with the novel's "dialogic tension" and its author's active engagement with contemporary political debate, this study is primarily concerned with the historical and philosophical roots of those tendencies that have been ascribed to a latent, sometimes affected, conservatism. ${ }^{4}$ I will argue that Opie's novel consciously challenges the Revolution's reflexive distrust of long-

\footnotetext{
${ }^{3}$ While critics such as Grenby, Gilmartin, Rooney, and Wood have examined the broader counterrevolutionary novel's intellectual roots, criticism of post-revolutionary women's writing has typically relied on the link between the French ideals propounded by the Revolution and British radical philosophy.

${ }^{4}$ For examples of the latter, see Ty 145-60. Shaffer, even more succinctly, argues that following the French Revolution, "women writers concerned about their reputations frequently apologized for immodestly pushing themselves into print and constrained themselves to writing conservatively only" (286).
} 
serving sociocultural institutions - propelled and emblematized by the influence of the Church - as antithetical to those "Enlightenment" ideals of liberty, equality, and justice. ${ }^{5}$

More specifically, Opie's reform program is one that relies on the constancy of change intrinsic to the natural world and the authority of factual historical processes in explaining the human condition. In this context, it could remain faithful to the lineage of Aristotelian natural law, descended through Edmund Burke in his standard-bearing assessment of the Revolution, and be adapted to the historical realities of English civil society and the burgeoning human rights tradition. ${ }^{6}$ In essence, Opie goes some way toward carving out a reinvigorated English national identity originating in right and founded not on the universalist cosmopolitan vision popularized by the French Declaration of Right but on social and moral codes distinctly and historically English. The historical context surrounding the novel lent this agenda immediacy because contemporary conflicts between libertinism and morality, order and disorder, and the spiritual and rational had their roots, one way or another, in the debates touched off by the Revolution and filtered through the radical pen of William Godwin. It is in Opie's novel that these issues are crystallized and the radical philosophies of Godwin given a reformist's interrogation. Most important, their fictional deployment emphasizes Opie's preeminence as a political philosopher amongst her contemporaries and further elucidates the theoretical and potentially reformist nature of the counterrevolutionary dialectic.

The novel tells the story of Adeline, introduced to readers as a young girl under the educational tutelage of her mother Editha Mowbray and her paternal grandmother Mrs. Woodville. While spending much of her time speculating on the best ways to educate her daughter, Editha ultimately leaves Adeline's practical education to Mrs. Woodville, who, "thinking it a pity that the poor girl should learn nothing, like, till she was to learn every thing, taught her according to the old way" (Opie 10-11). Nevertheless, Adeline espouses the Enlightenment-tinged social ideals promulgated - if not actually carried out - by her mother and finds their embodiment in the philosopher Frederic Glenmurray, with whom she elopes to the continent after being nearly assaulted by her mother's recent husband, Sir

\footnotetext{
${ }^{5}$ Taylor has argued that the term Enlightenment was eschewed in anti-Jacobin literature for the more propagandistic and conspiratorial philosophism and illumination; however, while the term itself may not yet have gone "from verb to noun" (307) during the revolutionary decade, the principles that would now characterize the era were fully understood by many counterrevolutionary writers, despite what Taylor views as conservative mystification in the face of "historical complexity" (299). For this reason, I have retained the term here.

${ }^{6}$ See Pappin.
} 
Patrick O'Carrol. Yet not long into their courtship, Glenmurray contracts an illness and, before dying, insists on Adeline's marriage to his brother Berrendale as the only means to protect her from her former association. Adeline accedes and, after the marriage, bears a child; Berrendale is found to have married the daughter of a Jamaican planter, thereby releasing Adeline from her marital obligations. Yet Adeline falls ill toward the end of the novel and entrusts the upbringing of her daughter to her mother, having been recently reconciled to her and offering her another chance at the education of a child. Adeline's subsequent death closes the novel and is the culmination of its authorial commentary, largely and aptly demonstrated throughout by her portrayal of sanguine educational theory, the durability of social institutions such as marriage, and the legal legacy of customs and traditions unique to sovereign nation-states.

The binary between Enlightenment metaphysics, derided by the loyalist opposition as speculative and utopian, and its ostensibly more empirical counterpart is represented by the educational theories propounded by Editha and the more practical guidance offered by Adeline's maternal grandmother. The description of Editha's enthusiasm for "abstruse systems of morals and metaphysics" and her immediate "neglect of positive duties" is directly juxtaposed against Mrs. Woodville's insistence on the attainment of "the trifling yet important details ... that women commonly know" (4) and is reflective of the tension that affords Adeline the skills to be practically useful but unable to ascertain those things unfit for practical use. As such, Adeline expends as much intellectual energy imbibing, as practical guides of conduct, "these new theories, and these romantic reveries" (14) as she does attending to those "every day operations" (11) necessary for the overall good of those in her immediate community. This is no more apparent than in Adeline's exclusive attendance on her grandmother during the elderly woman's last illness since Editha, "with every possible wish to be useful, had so long given way to habits of abstraction" (11). Indeed, while privileging domestic duty carries rather androcentric undertones, it is in keeping with the Enlightenment's renewed emphasis on the value of raising a responsible citizenry as well as traditionalist conceptions of the domestic as a model for a sustainable, self-governing, and naturally ordered state. ${ }^{7}$

Furthermore, the privileging of domestic duties and practical utility answers the maximizing principles of enlightenment collectivism and fulfills what Mark Murphy calls the particularity desideratum of natural law. That is, "the presence of a special tie to one's own laws, not just to those of any political community, or any minimally just political community" (86). Since natural law considers these

\footnotetext{
${ }^{7}$ See Mellor.
} 
special ties to be included in the pursuit of an aggregative common good, the pursuit of a singular good, in this case Adeline's treatment of her grandmother, does not preclude her from contributing to the common good of her given community. Mrs. Woodville has taught Adeline the "practical principle" of natural law, that "each person is bound to do his or her share for the common good," a concept fundamental to political authority (Murphy 86).

Editha's distortion of this principle has immediate implications for the novel's reflection of the revolutionary debate since she, in essence, comes to personify the anti-Jacobin caricature of the "man of the world," defined by the universal applicability of his ideals and his disdain for a society that could be rebuilt on axioms and a priori deductions. French Revolution historian Hippolyte Taine, like Burke, levied such charges against the radicals and ascribed to them the construction of a devastating and overly reductive scientific system used to explain arithmetically the human condition. ${ }^{8}$ The critique underscores the novel's rehearsal of Godwin's "general utility," as readers are told that Editha, "while professing her unbounded love for the great family of the world, suffered her own family to pine under the consciousness of her neglect" (Opie 4-5). Even more poignant is the character's declaration of support for the American colonists, an arguably anti-Jacobin literary trope deployed to articulate the dangers of idle political discourse and concomitant enthusiasm for any endeavor commenced under the aegis of natural right. Ever the cosmopolitan, Editha "had [not] even leisure to observe, that while she was feeling all the generous anxiety of a citizen of the world for the sons and daughters of American independence, her own child was imbibing, through her means, opinions dangerous to her well-being as a member of any civilized society" (15). That Editha has sacrificed filial duty and affection in favor of a certain cause célèbre in radical circles has ramifications enough and would have found a sympathetic audience on either side of the ideological divide. Yet most revealing is the dissonance expressed between the rhetoric of the cosmopolitan ideal and those features vital to the overall stability of individual nation-states. Again, the language here suggests a critique of the maximizing principles on which the cosmopolitan vision was formed. It is counterbalanced in the text by those common-good principles best articulated by a natural-law theory independent of the secular, subjectivist models conceived by Rousseau and adopted by French revolutionaries. ${ }^{9}$ For such thinkers and their archetype, Editha, "Revolutionary discourse regularly [could use] the language of the natural law to justify attacks on existing institutions" (Armenteros 111), an appropriation objected to by anti-Jacobin factions as a pretext for inciting revolution for its own sake. Chris Jones has also highlighted this tendency,

${ }^{8}$ See McClelland 251-54.

${ }^{9}$ See Tackett. For a contemporary rebuttal to Rousseau's Discourse, see Maistre. 
suggesting that "philosophical concepts, however integral to a particular system, became utopian and revolutionary when released from the social contexts in which they had seemed self-evident" (13).

That Editha's espousal and Adeline's literalist absorption of cosmopolitan ideals are seen to "[lay], perhaps, the foundation to herself and her mother of future misery and disgrace" (Opie 15) speaks to their power, if not their virtue. It is crucial to the text's proper placement amidst the revolutionary debate that Adeline's rationalist effusions for a sexual relationship "with no other ties or sanction than those of love and reason" (37) are met with "[shock] at hearing Adeline declare that her practice should be consonant to her theory" (28). This response from the purportedly enlightened class exposes deep divisions between "the bold in theory, and the almost impossible in practice" (21). Yet Editha's admonition to her daughter is even more revealing: "Little did I think that you were so romantic as to see no difference between amusing one's imagination with new theories and new systems, and acting upon them in defiance of common custom, and the received usages of society" (41). Here Editha's dedication to philosophy is betrayed as an exercise of the mind, redolent of the principal complaint put forward by the counterrevolution, that the dissemination of radical ideals to an indiscriminate populace would not yield justice but only unrest and disaffection.

Burke similarly accused Rousseau, arguing the seductiveness of dissent as directly proportional to the empty rhetorical gifts of its agent: "the paradoxes of eloquent writers, brought forth purely as a sport of fancy, to try their talents, to rouse attention, and excite surprise, are taken up by these [revolutionaries], not in the spirit of the original authors, as means of cultivating their taste and improving their style" (145). Mrs. Mowbray's indignation mimics that which Burke imagined Rousseau would have expressed had he lived to see the Revolution, predicting as he did that the great philosophe would indeed "be shocked at the practical frenzy of his scholars, who in their paradoxes are servile imitators; and even in their incredulity discover an implicit faith" (145). The similarity is striking, and, although it cannot be said to confirm Opie's own biases toward the philosophical system about which she writes, it does seem to reflect a very real objectivism regarding the consequences of its application, just or otherwise.

That Rousseau's influence on the revolutionary character was still being felt is evidenced by the presence of his works in the libraries of both Adeline and the loathsome Sir Patrick. Yet while Adeline has read Rousseau's Contrat Social, her reading of Julie is stopped short, preventing her from viewing the novel's overtly didactic second half. While readers of the entire novel would have presumably 
been left to conclude that works of social and political theory must be counterbalanced with lessons of experience, "Adeline becomes what every reader of conduct books and exemplary novels is supposed to be: a living application and exemplification of what she has read" (Bannet 120). Yet the omission is most pronounced when readers are told that Sir Patrick's literary exposure has been limited to "dangerous French novels" and other works "calculated to inflame the fancy and corrupt the morals" (Opie 55). Such literary fare marks Sir Patrick as the embodiment of radicalism gone awry, using virtue as a pretense for vice and social institutions as cover for predation and tyranny. ${ }^{10}$ It is no accident that Sir Patrick's attempt to corrupt the young Adeline is made through a series of lewd books deliberately left out for her perusal.

Yet the object of such a plot device is not to satirize contemporary worries about the baleful effects of novels on impressionable female minds. The relation of Sir Patrick's reading preferences allows Opie to elide the distinction between these and the "political tracts, systems of philosophy, and other romances" (55) familiar to Adeline. Indeed, reading any of them without proper knowledge of those sociohistorical circumstances informing a typically "English" culture would have constituted the very same inequitable educational structure so many progressive writers sought to ameliorate. Most representative is perhaps Mary Wollstonecraft, who, while promoting somewhat traditional notions of virtue and the domestic in light of the "sentimental lust" (65) that had prevailed in France, nevertheless recognized the double bind for women who were not properly educated and whose virtue was reductively and exclusively equated with chastity: "it is a farce to call any being virtuous whose virtues do not result from the exercise of its own reason" (86). This context, then, provides purchase to narrative condemnation of Adeline, who is, "owing to the pretty books which [Editha] let her read, living with [Glenmurray] as his mistress, and glorying in it, as if it was a notable, praiseworthy action" (98).

As Adeline will discover, a society's laws are more products of custom than they are simply arbitrary legislative exercises and thus are indeed unique to any given political community. Historian J. G. A. Pocock speaks to the evolution of British common and constitutional law, asserting that the "ideology of the Ancient Constitution was an elaborate set of historical arguments by which it was sought to show that the common law, and the constitution as it now stood, had been essentially the same since pre-Conquest times and-if the argument were pressed home-since time immemorial, or at least since an unrecorded beginning in the

\footnotetext{
${ }^{10}$ Many critics have noted the incongruousness of the violence committed against alleged enemies of the Revolution and the beneficence of the general will that facilitated it. See especially Parkin and Marshall.
} 
woods of Germany" (Pocock 94). Thus, Adeline's equation of custom and what she frequently terms "prejudice" is a false one, for the former cannot be dispensed with, even by sudden revolt, and must be made to ally with an equitable distribution of justice. It is, in fact, her relationship with Glenmurray that most clearly alerts readers to the tenuous position held by apostles of the radical movement, as the vision of a future end-state liberated from its institutional moorings often renders the material world of the present untenable. Glenmurray comes to symbolize this isolation, which evinces the tension between an idealist projection of the world as it ought to be and the material experience of the world as it is. While the philosopher ultimately defers to the practical half of the Humean dichotomy by being "contented to do homage to "things as they are"" (Opie 126), no amount of vacillation can prevent his beloved Adeline from engineering things as they should be.

Hints of Glenmurray's ambivalence toward his own strictures occur upon his introduction in the novel as "neither the blamelessness of his life, nor even his active virtue ... were deemed sufficient to counteract the mischievous tendency of his works" (21). Like Editha, Glenmurray has been ignorant of his philosophy's pragmatic underside, though upon recognizing Adeline's impending ruin, he expresses regret for having "led [Adeline] to a train of reasoning, so alluring in theory, [but] so pernicious in practice" (149). This is a reiteration of his earlier, self-abnegating reproach that "would to God I had never published" (70), a statement that, while not disavowing Enlightenment principles entirely, nevertheless reflects his regret for "opinions which were calculated to enlighten [the world]" (150). As a result of her devotion to social heterodoxy, equally admirable in its intentions, Adeline is compelled to endure with the repellent Berrendale that very same institution she so willfully rejected.

However, the novel's most condemnatory appraisal of the radical program occurs when Glenmurray retrospectively adopts the language of the counterrevolution: "as those opinions militated against the experience and custom of ages, ought I not to have paused before I published, and kept them back till they had received the sanction of my maturer judgment?" (150). In addition to invoking once more the natural-law principle that custom often determines legitimate legal authority, the allusion to his publications as the result of youthful fancy also serves to discredit them not only as indiscreet, but as ignorant of the material wisdom derived from communal experience. ${ }^{11}$ As Glenmurray's protestations would

\footnotetext{
${ }^{11}$ This statement also serves to reinforce King and Pierce's explanation of Opie's liberality in constructing the ages of her principal characters, given that their inspiration, Wollstonecraft and Godwin, were 38 and 41, respectively, when they married (note 70). However, while the editors claim the youth of Adeline and Glenmurray is meant to evoke a sympathetic response from
} 
suggest, custom is not a usurper of natural justice and right but rather derives from a society's patterns of behavior deemed reasonable by rules of consent and constitutive of decisive reasons for action. On this basis, it is inferred that, while law can be changed or amended, it will be done by the cumulative and collective actions of a given political community over a period of time.

It is of some moment, then, that the most credible and consistent voice in the text is one of conservative opposition, found in the Quaker Mrs. Pemberton, whose own invocation of natural law marks the coalescence of revealed truths and historically organic systems for ordered society. Gently and somewhat condescendingly identifying Adeline with the "pernicious doctrine," Mrs. Pemberton appropriates the principal criticism levied at the new philosopher:

Poor thing! I understand thee now-Thou art one of the enlightened, as they call themselves-Thou art one of those wise in their own conceit, who, disregarding the customs of ages, and the dictates of experience, set up their own opinions against the hallowed institutions of men and the will of the Most High. (122)

Augmenting the traditions of the revolutionary decade, this particular speech would also resonate with a culture increasingly wary of rejecting material wisdom for scientific and metaphysical knowledge.

Moreover, the treatment of theory's place in an ordered society enables readers to detect a realist metaphysics compatible with the counterrevolution's appropriation of neo-scholastic traditions. Joseph L. Pappin notes the presence of such language at the time, arguing that "while both [Burke and Aquinas] hold to a realist philosophy in the realm of metaphysics, both likewise recognize that an a priori form of rationalist ethics cannot be applied to circumstances without the intervening activity of the first of all virtues, which is prudence" (225). Furthermore, in part given its intensified scrutiny by the British political establishment, much of the post-revolutionary reform movement had to be cognizant of its singular historical moment, echoing the scholastic imperative that "the historical development of civilizations and cultures circumscribes and designates the parameters within which we will normally act with prudence." (215). However, Adeline's actions oppose such counsel, and thus her futile universalist wish to "act independent of society" (Opie 112) becomes paradigmatic of what Noel Reynolds refers to as the "utilitarian liberalism" instigated by the abstract French Declaration of Right. As Reynolds comments,

readers, this speech from Glenmurray, if we are to accept the editorial note, may then also be a damning critique of these eminently more "experienced" purveyors of the new philosophy. 
"the French declaration articulates a theory of liberty and its limitation by law in terms of universal criteria: liberty is the power of doing whatever does not injure another, and law should only prohibit actions that are hurtful to society" (Reynolds 194). Adeline hopes her actions will stimulate a social regeneration free from prejudice but ultimately begins to realize that her actions are not as benign as their stimulus would suggest. In fact, they are seen to violate even the utilitarian law she has so willfully imbibed.

Yet even more material to the text's counterrevolutionary undercurrent, Glenmurray's disaffection toward the secularist rationalism of the European Enlightenment has implications for not only the enduring persistence of social institutions over time, but for the role of revealed religion during that time as well. As Opie's readers would have been aware, the individualism of the revolutionary ideology was often presented with religious zeal, a final point reinforced by the hitherto atheistic Glenmurray:

Perhaps, had I remained longer here, we might have [worshipped together]; for though my feelings have continually hurried me into adoration of the Supreme Being, I have often wished my homage to be as regular and as founded on immutable conviction as it once was: but it is too late now for amendment, though, alas! not for regret, deep regret. (Opie 157)

Glenmurray's conversion here confirms what had been suspected of members of the radical Jacobin sect, that an indulgence of individual impulses, particularly those contrary to custom's established law, necessarily came at the expense of natural progress and an actual, unquantifiable common good. ${ }^{12}$ For Adeline, who admits that "with you, and you alone, is the gratification of self always a secondary consideration" (156), peace, or in this case, happiness as a means-end entity, is entirely self-referential, reminiscent of the Hobbesian state of nature in which common pursuits are nonexistent and peace is desired less for its own sake than for the cynical preservation of self (Murphy 61-62). Glenmurray, though repentant of the errors inculcated in the name of a general good, is vindicated only by the transference to those who survive him of the lessons of experience and the wisdom gained by them. Before comforting the disconsolate Adeline, Mrs. Pemberton says as much, regretting the fate of Glenmurray, "wise in thine own conceit, who presumedst sometimes to question even the existence of the Most High, and to set up thy vain chimeras of yesterday against the wisdom and experience of centuries" (Opie 160). The ineluctable truths of Mrs. Pemberton

\footnotetext{
${ }^{12}$ For more on the French Declaration as the basis of individual will and subsequent right, see Chapter 3 of d'Entrèves.
} 
directly counter those proffered by Adeline, and as the text unfolds, they come to supplant modern correctives to what are presented as natural deviations from custom's laws. ${ }^{13}$

Yet for Adeline, receipt of this knowledge is deferred until she prevails upon Glenmurray to enact his own system of principles, a development only the philosopher himself acknowledges as paradoxically prohibitive, noting ominously, "the name of wife imposes restraint even on a libertine" (71). In this case, he perhaps understands what an inexperienced Adeline cannot: that although marriage may have degenerated into its current state and deserved censure, it nevertheless afforded the kind of mobility Adeline would be without should she proceed as intended. Wollstonecraft herself had made a similar observation and may be argued to have influenced Opie's consideration of marriage. She writes, "The personal reserve, and sacred respect for cleanliness and delicacy in domestic life, which French women almost despise, are the graceful pillars of modesty; but, far from despising them, if the pure flame of patriotism have reached their bosoms, they should labour to improve the morals of their fellow-citizens" (66). Here Adeline's protestations against marriage are not only emblematic of debates over the institution itself, but ramified especially when placed in the context of eighteenth-century separate sphere ideology. As Linda Colley argues, "separate sphere rhetoric could supply a way for women to assert their important role in British society and to protect their rights such as they were" (262-63). That the authority granting marriage's official sanction in the novel seems largely biblical, that point is arguably superseded by its implications for the era's debates over secular morality and the moral legitimacy of the revolutionary ethos. Adeline's subsequent resistance is indeed revolutionary in that it deliberately undercuts an established and lawful — not to say infallible - program of order. Yet its catastrophic effects, melded with revolutionary regret, tend to mitigate what would otherwise be a standard feminist interrogation of gendered hierarchy.

Instead, the object of critique becomes the ostensibly restorative revolutionary program itself rather than those corruptions of order-preserving social institutions. This is perhaps made most clear by Adeline's treatment in polite society, where, instead of being upheld as a paragon of virtue by those ostensibly "liberal and unprejudiced persons in the world" (68), she is mocked as a "goddess" (76) and an "angel of purity" (74) and repudiated as a kept woman. And while the conjugal hypocrisies of those Adeline encounters offer an ingenuous critique of the marriage state, the development of the novel's main characters offers something much more fundamental. Unwilling to accede to "the trammels which [society]

\footnotetext{
${ }^{13}$ For more on the link between positive law and custom in England, see Christianson 115-84.
} 
imposes" (127), Adeline blithely equates reform with untempered rebellion, scorning realities forged by civil society's organic development. After a series of disagreeable advances by men seeking to exploit the easy misconstrual of liberty for avowed sexual license, the narrative tone reveals that Adeline's rationalizing may be as much an object of satire as sympathy. Adeline, in the tradition of Mary Hays, wonders why, "because an idle ceremony has not been muttered over me at the altar, [she] is liable to be thought a woman of vicious inclinations, and to be exposed to the most daring insults" (116). At this point in the text, any negative judgment on Adeline, if not for social heterodoxy or at least mere imprudence, is prompted by the narrator, who seems to deride Adeline's impractical adherence to misdirected principle. Opie writes, "as these reflections occurred to her, she could scarcely help regretting that her principles would not allow her delicacy and virtue to be placed under the sacred shelter bestowed by that ceremony which she was pleased to call idle" (116). Despite its shortcomings, also evident here, this particular institution carries with it an authoritative protection that transcends cultural adaptations or a professed independence of it. The reform vision is thus left intact since to dispense completely with such a firmly rooted tradition was to create new and perhaps even greater tyrannies.

However, Opie's illustrations of marriage's ignoble underside and the fact that "[Glenmurray and Adeline's] 'marriage' is superior to any other heterosexual relationship in the novel" have been frequently cited by critics as evidence of the author's progressivism (Eberle 136). Yet despite narrative admission of marriage's tendency to "perpetuate the dearest of all monopolies" (Opie 38), it nevertheless comes to embody the natural law tradition of the counterrevolution by depicting the influence of human behavior over time and the fulfillment of natural desire as the sources of society's most determinable institutions. This can also be seen to challenge the conceit that these institutions had been somehow manufactured as vehicles for state control. ${ }^{14}$ That Adeline's relationship with Glenmurray, a model for companionable marriage and lacking nothing but society's imprimatur, is the most virtuous in the text is as much an endorsement of marriage's potential to foster equity as it is a repudiation of it as irredeemably unjust. Adeline's early opposition to marriage suggests as much, since it in hindsight signaled her unqualified intent:

With an unreserve which nothing but her ignorance of the world, and the strange education which she had received, could at all

\footnotetext{
${ }^{14}$ Scott asserts the "connection between authoritarian regimes and the control of women" (47) and offers the groundwork for a critique of the ways in which marital arrangements have been analogized (and thereby reinforced) throughout history to construct political relationships "between ruler and ruled" (46).
} 
excuse, [Adeline] began to declaim against marriage, as an institution at once absurd, unjust, and immoral, and to declare that she would never submit to so contemptible a form, or profane the sacred ties of love by so odious and unnecessary a ceremony. (28)

The implied critique of Adeline's resolution at this point in the text serves a dual purpose. Adeline might be pitied her impulse and ignorance. It must be considered, though, that her renunciation of marriage and subsequent elopement with Glenmurray had been catalyzed by Sir Patrick's plotted rape of Adeline, who, while "strong in innocence" (60), realized that such license was only made possible by Sir Patrick's (bigamous) marriage to her mother.

Sir Patrick's actions toward Adeline represent the convenient elasticity of the Enlightenment's regenerative philosophy. They also signal a critique of an institution that, having been corrupted over time, remained socially salutary when constructed on equitable terms. Editha's rationalization that her marriage "was absolutely necessary to my happiness" (50) accords with Glenmurray's entreaty to Adeline that "your only chance for happiness is becoming a wife" (150). Both statements are seeming utilitarian projections of happiness that are counterbalanced by their high cost. That cost is here manifested not only by inequitable marriage settlements but also the depiction of libertinism granted legitimacy by matrimonial sanction. Accordingly, Glenmurray's assertion that "no wife was ever more pure than Adeline" (74) suggests as much a denunciation of "false" marriage as a renegotiation of equitable and companionate marriage in the name of civil progress. Moreover, that Adeline is rejected as a "fallen angel" (74) by those who have themselves taken extramarital liberties provides further commentary on the unwarranted protection marriage affords to those wishing to lead lives of physical self-indulgence and dissipation.

Necessarily, then, marriage as a naturally edifying social institution, and hence one consistent with the novel's deployment of natural-law principles, is ultimately upheld by Adeline herself. While her repudiation of former ideals is not perhaps as fervent as Glenmurray's, Adeline's holds much greater purchase, since it is affixed to a staunch defense of that previously rejected as provincial and disingenuous. Having been notified of Berrendale's bigamy and her consequent release from marriage's confines, Adeline is effusive:

I have no doubt that there is a great deal of individual suffering in the marriage state; but I believe that the mass of happiness and virtue is certainly increased by it. Individual suffering, therefore, is no more an argument for the abolition of marriage, than the 
accidental bursting of a musquet would be for the total abolition of fire-arms. (217)

For Adeline, her release from an oppressive marriage would be to submit to the idea of the institution as fluid and undoubtedly in line with the contractarian line of the radicals. ${ }^{15}$ However, Adeline here seems to recognize marriage as legitimated by the reasonable progress of ages, sanctioned by customs cumulatively and collectively authoritative. Such methodology was not absent in England, as James Mackintosh's affirmation of immutable progress confirms: "Such a body of political laws must in all countries arise out of the character and situation of a people; they must grow with its progress, be adapted to its peculiarities, change with its changes, and be incorporated with its habits" (236). However, Mackintosh directly confronts the corruption of those laws born of custom and gives pride of place to the humanist impulse as it was refracted through a Scholastic lens, writing that "the appropriate praise of this [Christian] religion is not so much that it has taught new duties, as that it breathes a milder and more benevolent spirit over the whole extent of morals" (236). As is also seen in Opie, this theory of civil society defers to wisdom gained by the experience of ages and the authority granted by a natural civic humanism, articulated, if not always propounded, by Christianity. Adeline's strikingly similar exhibition of civic humanism and "rational conviction" is directly opposed to her prior selfreferential worldview, one which confounded custom with "prejudice" and impelled her to renounce the former rather than seek to reform the latter. Eradication or denial of the system itself, as evidenced by Adeline's story, breeds greater tyrannies and loss of the authority that, in its ideal state, preserves the natural liberties of the individual.

In this way, the novel confronts the typical reluctance of critics to admit "any evidence of conservative bias on Opie's part" (King and Pierce, xii ), ultimately asserting that marriage, when based on cultivated affections and upheld by mutually equitable obligations, serves a greater overall good than a wholesaleand predominantly self-satisfying - renunciation of it. As Adeline argues, "it follows that marriage must be more beneficial to society in its consequences, than connections capable of being dissolved at pleasure; because it has a tendency to call forth and exercise the affections, and control the passions" (Opie 237). Here, the seeming restraints imposed by such obligations serve as an anodyne to the otherwise unchecked passions that, inevitably expanding into other realms of civil society, promote social decay and breed tyranny. Adeline says as much in the ensuing paragraphs, finally concluding that "marriage is a wise and ought to be a

\footnotetext{
${ }^{15}$ See White $80-84$.
} 
sacred institution; and I bitterly regret the hour when ... I dared to think and act contrary to this opinion" (238). Given the social and historical context of the novel, then, Adeline's "fatal error of opinion" (237) regarding marriage may serve as a representative critique of revolutionary means, and she would perhaps have agreed with Burke "that no man should approach to look into its defects or corruptions but with due caution" and, furthermore, "that he should never dream of beginning its reformation by its subversion" (82).

However, it must be remembered that Adeline's vision throughout had been the overall improvement of her society, an admirable exercise in light of the social and political stagnation that followed closely on the heels of the French Revolution. Hence Eleanor Ty's assertion that Opie may be viewed "as an author who sympathized with and understood what the radicals were espousing, but who remained distant enough to perceive the difficulties of practicing their theories without there being changes in society at large" (151). It is precisely this point, however, which may tend to oversimplify Opie's apprehension of radical ideals and undermine her vision for an equitable society, one that deliberately distanced itself from the revolutionary program. Her heroine's statements, it would seem, suggest that the construction of a reinvigorated reformist culture must now be the product of the steady presence of historical contexts fused with the organically progressive elements of generational legacies.

Quite appropriately, then, Adeline must sacrifice her happiness for the benefit of a greater future good, clearly manifested by the prospects of her daughter by Berrendale, the aptly named Editha. For Adeline, social progress and the roots of reform are founded in the cumulative knowledge of generations and deference to the inevitable directives of experience. At this late point in the text, the emphasis on Adeline's education comes full circle, as the heroine advances a system in which personal gratification or self-indulgence-however principled it may seem-must not be pursued in opposition to the more natural impulses of constancy and maternal duty. She reasons, "it is evident that on the education given to children must depend the welfare of the community; and consequently, that whatever is likely to induce parents to neglect the education of their children must be hurtful to the welfare of the community" (237). Adeline's former principles violated these dictates in much the same way her mother's did. Despite their intent, they are seen in the text as most harmful for their abnegation of filial duties.

Such is the wisdom which Adeline bequeaths to her daughter, as she, like Glenmurray, cannot live to see her past offenses expiated by her own contrition. Her mistakes become part of the education of the young Editha, whose lessons 
need not be learned solely by her own experience, but that of her mother before her. Yet the effects of her actions are lasting, and Adeline realizes the harmful legacy they will leave for her daughter, in spite of her renunciation of them: "I was as great a stumbling block to others as if the life I led had been owing to the influence of lawless desires" (239). Thus, should Adeline live to undertake the education of young Editha, her presence will serve merely to symbolize the incongruity of her past life to her current principles: "Even if I were not conscious of having by my example led another into the path of sin, still, for my child's sake I should wish to die" (240). In essence, the motives for her actions are superseded by the actions themselves, and consequently her continued presence in the life of her daughter will be a hindrance to her practical education.

Because Adeline's fate, like Glenmurray's before her, is bound to those principles she so steadfastly espoused, it is ultimately Mrs. Mowbray who is offered atonement, reminded as she is by Mrs. Pemberton that "thy daughter's faults originated in thee! her education was cruelly defective" (250). And in a seeming nod to a Burkean empiricism, readers are left to conclude what Editha could only in hindsight: "how necessary was to [Adeline] the warning voice of judgment and experience!" (251). Here Opie combines the pervasive emphasis on children's education with the continued critique of the effects of the radical philosophy. In doing so, she also suggests the possibility for vindication through the advent of a new generation, appositely represented by Mrs. Mowbray's young namesake. Having lived long enough to regret her life's course of action, Adeline, before her death, channels the Quaker Mrs. Pemberton, marking a more classical "revolution" back to those childhood instincts contravened by her mother's educational theory: "Oh! teach my Editha to be humble, teach her to be slow to call the experience of ages contemptible prejudices; teach her no opinions that can destroy her sympathies with general society, and make her an alien to the hearts of those amongst whom she lives" (259). Adeline has deferred to the dictates of custom as the natural offspring of a civilized society and recognizes the presence of each individual within his or her political community as essential to its continued progress. By demonstrating the alienating and divisive effects of a complete rupture of normative codes, Opie reinforces the notion that the vitality of a culture is the product of its roots and that recourse to any violations of natural right and justice must include due consideration of them.

Such an approach grants that the source and exercise of legislative authority are indeed imperfect and, in some cases, unjust, but they are nevertheless informed by the customs of a distinctive English society. While detractors would ascribe to the defense of such a system those isolationist and provincial tendencies forsworn by the revolutionary establishment, Opie, in fact, combines this somewhat more 
nationalistic vision of custom with the realist notion that right derives from that custom's origination of rights-preserving law. The author also seeks to rescue the fading hope of social reform from the jaws of revolution, affirming the continued progress of the civilized state by obedience to those laws made manifest by custom, practical reason, and moral prudence. In this way, the novel is revolutionary in a more classical sense than those of Opie's radical forerunners in that it envisions a society returned to its pre-revolutionary ideals based on the collective and practical actions of its citizens. In an epoch that commonly rejected history and tradition as inimical to social and political progress, Opie's conservative turn in many ways emerges as an innovation well suited for lasting and meaningful reform. 


\section{Works Cited}

Armenteros, Carolina. "From Human Nature to Normal Humanity: Joseph de Maistre, Rousseau, and the Origins of Moral Statistics." Journal of the History of Ideas, vol. 68, no. 1, January 2007, pp. 107-30.

Bannet, Eve Tavor. The Domestic Revolution: Enlightenment Feminisms and the Novel. Johns Hopkins UP, 2000.

Burke, Edmund. Reflections on the Revolution in France, edited by Frank M. Turner, Yale UP, 2003.

Christianson, Paul. "Ancient Constitutions in the Age of Coke and Selden." The Roots of Liberty: Magna Carta, Ancient Constitution, and the AngloAmerican Tradition of Rule of Law, edited by Ellis Sandoz, Liberty Fund, 1993, pp. 115-84.

Colley, Linda. Britons: Forging the Nation 1707-1837. 2nd ed. Yale UP, 2005.

d'Entrèves, A. P. Natural Law: An Historical Survey. Harper \& Row, 1965.

Eberle, Roxanne. "Amelia Opie's Adeline Mowbray: Diverting the Libertine Gaze; or, The Vindication of a Fallen Woman." Studies in the Novel, vol. 26, no. 1-2, 1994, pp. 121-152.

Gilmartin, Kevin. Writing Against Revolution: Literary Conservatism in Britain, 1790-1832. Cambridge UP, 2007.

Grenby, M. O. The Anti-Jacobin Novel: British Conservatism and the French Revolution. Cambridge UP, 2001.

Hancock, Ralph C., and L. Gary Lambert, editors. The Legacy of the French Revolution. Rowman \& Littlefield, 1996.

Jones, Chris. Radical Sensibility: Literature and Ideas in the 1790s. Routledge, 1993.

King, Shelley, and John B. Pierce. Introduction. In Opie, pp. vii-xxxii. 
King, Shelley. "Politics, Poetics, and Propriety: Reviewing Amelia Opie." Romanticism on the Net, vol. 29-30, February-May 2003, http://id.erudit.org/iderudit/007720ar.

Korobkin, Laura H. "'Can Your Volatile Daughter Ever Acquire Your Wisdom?': Luxury and False Ideals in The Coquette." Early American Literature, vol. 41, no. 1, 2006, pp. 79-107.

Mackintosh, James. "A Discourse on the Law of Nature and Nations." Vindiciae Gallicae and Other Writings on the French Revolution, edited by Donald Winch, Liberty Fund, 2006, pp. 203-49.

Maistre, Joseph. Against Rousseau: "On the State of Nature" and "On the Sovereignty of the People," edited and translated by Richard Lebrun, McGillQueen's University Press, 1996.

Marshall, Terence. "Human Rights and Constitutional Government." Hancock and Lambert, pp. 151-74.

McClelland, J. S. A History of Western Political Thought. Routledge, 1996.

Mellor, Anne K. Mothers of the Nation: Women's Political Writing in England, 1780-1830. Indiana UP, 2000.

Murphy, Mark C. Natural Law in Jurisprudence and Politics. Cambridge UP, 2006.

Opie, Amelia. Adeline Mowbray, or the Mother and Daughter, edited by Shelley King and John B. Pierce, Oxford UP, 1999.

Packham, Catherine. "History, the Novel, and the French Revolution." The Eighteenth Century: Theory and Interpretation, vol. 57, no. 1, 2016, pp. 14549.

Pappin, Joseph L., III. "Edmund Burke and the Thomistic Foundations of Natural Law." An Imaginative Whig: Reassessing the Life and Thought of Edmund Burke, edited by Ian Crowe, University of Missouri Press, 2005, pp. 203-27.

Parkin, Charles W. The Moral Basis of Burke's Political Thought. Cambridge UP, 1956.

Pocock, J. G. A. Virtue, Commerce, and History: Essays on Political Thought and History, Chiefly in the Eighteenth Century. Cambridge UP, 1985. 
Reynolds, Noel B. "The Rule of Law in Eighteenth-Century Revolutions." Hancock and Lambert, pp. 189-98.

Rooney, Morgan. The French Revolution Debate and the British Novel, 17901814: The Struggle for History's Authority. Bucknell University Press, 2013.

Scott, Joan Wallach. Gender and the Politics of History. Revised edition. Columbia University Press, 1999.

Shaffer, Julie. "Ruined Women and Illegitimate Daughters." Lewd and Notorious: Female Transgression in the Eighteenth Century, edited by Katharine Kittredge, University of Michigan Press, 2003, pp. 283-318.

Tackett, Timothy. Becoming a Revolutionary: The Deputies of the French National Assembly and the Emergence of a Revolutionary Culture, 17891790. Princeton UP, 1996.

Taylor, Michael. "British Conservatism and the Illuminati Conspiracy." Eighteenth-Century Studies, vol. 47, no. 3, Spring 2014, pp. 293-312.

Ty, Eleanor. Empowering the Feminine: The Narratives of Mary Robinson, Jane West, and Amelia Opie, 1796-1812. University of Toronto Press, 1998.

Wake, Ann Frank. "Indirect Dissent: 'Landscaping' Female Agency in Amelia Alderson Opie's Poems of the 1790s." Rebellious Hearts: British Women Writers and the French Revolution, edited by Adriana Craciun and Kari E. Lokke, State University of New York Press, 2001, pp. 261-91.

Wallace, Miriam L. Revolutionary Subjects in the English "Jacobin" Novel, 1790-1805. Bucknell University Press, 2009.

White, R. S. Natural Rights and the Birth of Romanticism in the 1790s. Palgrave Macmillan, 2005.

Wollstonecraft, Mary. A Vindication of the Rights of Woman. A Vindication of the Rights of Men; A Vindication of the Rights of Woman; An Historical and Moral View of the French Revolution, edited by Janet Todd, Oxford UP 1998, pp. 63-283.

Wood, Lisa. Modes of Discipline: Women, Conservatism, and the Novel after the French Revolution. Bucknell University Press, 2003. 